\title{
Cellular localization and cell cycle regulation by a temperature-sensitive p53 protein
}

\author{
Jesse Martinez, Ingo Georgoff, Joanne Martinez, and Arnold J. Levine ${ }^{1}$ \\ Department of Molecular Biology, Princeton University, Princeton, New Jersey 08544-1014 USA
}

Primary rat embryo fibroblasts were transformed by a p 53 mutant (alanine to valine change at amino acid 135) plus ras. This $\mathrm{p}^{\mathrm{v} 3^{\mathrm{val135}}}$ mutant is temperature sensitive for a conformational change detected by the binding of a monoclonal antibody, PAb246, which recognizes the wild-type protein or the great majority of $\mathrm{p} 53^{\text {val1 } 35}$ at $32.5^{\circ} \mathrm{C}$. At $37^{\circ} \mathrm{C}$, both mutant and wild-type p53 conformational forms co-exist in the cells, while at $39.5^{\circ} \mathrm{C}$, the majority of the p53 $3^{\text {val135 }}$ in the cell is in a mutant conformation not recognized by PAb246 antibody. At $39.5^{\circ} \mathrm{C}$, the mutant p53 is localized in the cytoplasm of the cell. At $32.5^{\circ} \mathrm{C}$, the p53 protein enters the nucleus and stops the growth of these cells. At $37^{\circ} \mathrm{C}$ where there is a mixture of mutant and wild-type p53, the wild-type p53 protein is in a complex with hsc70 and mutant p53 protein in the cytoplasm of the cell during $\mathrm{G}_{1}$. This wild-type protein enters the nucleus as the cells enter the S-phase of the cell cycle. At $32.5^{\circ} \mathrm{C}$, the cells stop replication and arrest at the $G_{1} / S$ border. After $48 \mathrm{hr}$ at $32.5^{\circ} \mathrm{C}, 91 \%$ of the cells are in the $G_{1}$ fraction of the cell cycle. The S-phase cells appear to be immune to the p53 negative regulation of growth until they enter the next $G_{1}$ period. These data strongly suggest that mutant p53 proteins in transformed cells act to sequester the wild-type p53 protein in an hsc70-p53 complex, which resides in the cytoplasm during the stage of the cell cycle, $G_{1}$, when nuclear wild-type p53 would normally act to regulate cell growth and progression through the cycle. In this way, mutant p53 proteins can act in a trans-dominant fashion to overcome growth regulation by the wild-type p53 allele and protein in a cell.

[Key Words: p53 mutant; rat embryo fibroblasts; transformed cells]

Received September 19, 1990; revised version accepted November 19, 1990.

Several lines of evidence now indicate that the p53 gene product can regulate the growth and replication of cells and that mutant forms of this protein or viral oncogene products can alter this regulation. The wild-type p53 protein has the ability to suppress the transformation of cells in culture by viral or cellular oncogenes (Eliyahu et al. 1989; Finlay et al. 1989). In addition, the reintroduction of wild-type p53 into a transformed cell blocks cell growth (Baker et al. 1990; Diller et al. 1990; Mercer et al. 1990). Mutant forms of p53 will cooperate with the ras oncogene and mediate transformation of primary rat embryo fibroblasts in cell culture (Eliyahu et al. 1988; Hinds et al. 1989). These mutant $\mathrm{p} 53$ proteins act in cells that have endogenous wild-type p53 proteins (Finlay et al. 1989) so as to overcome this normal regulatory function. The mutations that activate the p53 protein so that it can transform cells are usually missense mutations that map between amino acid residues 118 and 307 (of 390393 amino acids; Levine 1990). They produce p53 proteins with an altered conformation, as detected by the failure of monoclonal antibody PAb246 (Yewdell et al.

${ }^{1}$ Corresponding author.
1986) to recognize these mutant proteins (Tan et al. 1986; Finlay et al. 1988) and the ability of antibody PAb240 to specifically bind to some mutant p53 protein (Bartek et al. 1990). Along with this altered conformation, many mutant p53 proteins also bind to the cellular heat shock protein, hsc70 (Hinds et al. 1987; Finlay et al. 1988). Common to all p53 missense mutations is a greater stability of the protein or a longer half-life (Reich and Levine 1984; Finlay et al. 1988; Iggo et al. 1990). This results in a much higher concentration of mutant p53 in transformed cells (Linzer and Levine 1979; Crawford et al. 1981; Dippold et al. 1981; Thomas et al. 1983) and tumors (Iggo et al. 1990). Indeed, it is clear that a high concentration of mutant $\mathrm{p} 53$ protein in a cell is required to contribute efficiently to the transformation event (Hinds et al. 1989). Finally, several virus-encoded oncogene products from SV40, the group $\mathrm{C}$ adenoviruses, and the human papilloma viruses HPV-16 and HPV-18 bind to p53 and may well mediate their transforming activities via the p53 protein (Lane and Crawford 1979; Linzer and Levine 1979; Sarnow et al. 1982; Werness et al. 1990).

In this study an examination was undertaken to deter- 
mine how mutant $\mathrm{p} 53$ protein in a cell can overcome the regulation of endogenous wild-type p53 proteins and transform a cell. Two murine p53 mutants, $\mathrm{p} 53^{\text {val } 135}$ (an alanine to valine change at residue 135) (Eliyahu et al. 1985; Hinds et al. 1989) and p53 ${ }^{\mathrm{KH} 215}$ (an insertion of four amino acids at residue 215) (Tan et al. 1986) were employed to transform primary rat embryo fibroblasts in cooperation with the ras oncogene. High levels of these murine mutant p53 proteins were expressed in these cells along with lesser amounts of the rat p53 protein (Finlay et al. 1989). A polymerase chain reaction (PCR) amplification of the reverse transcriptase copy of the rat p53 mRNA from both p53 $3^{\text {vall } 135}$ and $\mathrm{p} 53^{\mathrm{KH} 215}$ plus rastransformed cells was sequenced. This showed that the endogenous rat $\mathrm{p} 53$ mRNA and protein was a wild-type copy of $\mathrm{p} 53$. The murine mutant $\mathrm{p} 53$ protein, the wildtype rat $\mathrm{p} 53$ protein, and the cellular heat shock protein hsc70 were found in an oligomeric protein complex in these cells (Finlay et al. 1989). It has been suggested that the murine mutant $\mathrm{p} 53$ protein could sequester the wildtype rat p53 protein and inactivate its ability to negatively regulate growth in these cells (Baker et al. 1989; Finlay et al. 1989).

In agreement with Michalovitz, et al. (1990), the p53 $3^{\text {val135 }}$ mutant is shown to be temperature sensitive. At $32.5^{\circ} \mathrm{C}$, the great majority of this $\mathrm{p} 53$ protein is in the wild-type conformation (PAb246 $\left.{ }^{+}, \mathrm{PAb} 40^{-}\right)$, whereas at $39.5^{\circ} \mathrm{C}$, most of this $\mathrm{p} 53$ protein is in the mutant conformation $\left(\mathrm{PAb} 246^{-}, \mathrm{PAb} 240^{+}\right)$. At $39.5^{\circ} \mathrm{C}$, during the $\mathrm{G}_{1}$ phase of the cell cycle, the transformed cells replicate rapidly; whereas at $32.5^{\circ} \mathrm{C}$, cell growth stops and the cells are blocked at the $G_{1} / S$ border of the cell cycle. Those cells in S-phase continue through the cell cycle to the next $\mathrm{G}_{1} / \mathrm{S}$ border. At $39.5^{\circ} \mathrm{C}$, the p 53 mutant protein is localized in the cytoplasm, while at $32.5^{\circ} \mathrm{C}$, the p53 protein is in the nucleus. At $37^{\circ} \mathrm{C}$ where both mutant and wild-type 53 coexist in these transformed cells, the mutant p53-wild-type p53-hsc70 complex (Hinds et al. 1987) is in the cytoplasm during the $G_{1}$ phase of the cell cycle. The wild-type p53 proteins move into the nucleus at the start of the S phase. Thus, wild-type p53 appears to be sequestered in the cytoplasm during a critical time, $G_{1}$, when it could act in the nucleus to block entry into the $\mathrm{S}$ phase. As such, mutant p53 acts dominantly to sequester the wild-type p53 protein in a place where it cannot function. The $\mathrm{p} 53^{\mathrm{KH} 215}$ mutant protein, which is not temperature sensitive, remains in the cell cytoplasm throughout the cell cycle $\left(\mathrm{PAb}^{-}, \mathrm{PAb} 40^{+}, \mathrm{hsc} 70^{+}\right.$ complex) (Hinds et al. 1987).

\section{Results}

\section{Characterization of $p 53$ plus ras-transformed cells lines}

The murine p53 val135 mutant (Eliyahu et al. 1985) and p53 ${ }^{\mathrm{KH} 215}$ mutant clones (Tan et al. 1986) were employed, along with an activated ras oncogene, to transfect primary rat embryo fibroblasts and isolate transformed cell lines (Hinds et al. 1987; Finlay et al. 1988). These cell lines were shown to express high levels of mutant murine 53 proteins and ras (Hinds et al. 1987; Finlay et al. 1988). When PAb246 (recognizes wild-type murine p53) and PAb240 (recognizes mutant p53) (Yewdell et al. 1986; Iggo et al. 1990) were employed to follow the conformation of these $\mathrm{p} 53$ proteins, using either fluorescent antibody tests or immunoprecipitation, the p53 $3^{\text {val135 }}$ mutant was temperature sensitive for antibody binding, with the great majority of this protein being in the wildtype conformation at $32.5^{\circ} \mathrm{C}$ and mutant at $39.5^{\circ} \mathrm{C}$ (Table 1). In A1-5 cells (p53 val135), there was three times more mutant $\mathrm{p} 53$ than wild type at $39.5^{\circ} \mathrm{C}$ and four times more wild-type p53 than mutant at $32.5^{\circ} \mathrm{C}$. The total levels of p53 (mutant or wild-type) synthesized at $39.5^{\circ} \mathrm{C}$ was greater than at $32.5^{\circ} \mathrm{C}$, and this was due to both the temperature differential and the fact that the mutant form of p53 has a longer half-life than the wild-type form of p53 in Al-5 cells (Finlay et al. 1988). At $39.5^{\circ} \mathrm{C}$, the estimate of PAb246 detecting wild-type p53 $(27 \%)$ is very likely an overestimate because at this temperature, the wildtype p53 is in a complex with mutant p53 and rat p53 (Finlay et al. 1988; also see Fig. 5), which adds to the percentage of p53 detected by this antibody in a onedimensional gel autoradiogram. Thus, the $3: 1$ ratio of mutant to wild-type p53 at $39.5^{\circ} \mathrm{C}$ is a minimum estimate, and the phenotype of these cells at $39.5^{\circ} \mathrm{C}$ is clearly transformed. This shift in mutant or wild-type p53 conformations was not seen with $\mathrm{p} 53^{\mathrm{KH} 215}$ plus ras cells (T101-4 cells), which was in the mutant conformation at all temperatures. In addition, the p53 $3^{\mathrm{KH} 215} \mathrm{mu}$ tant at $32.5^{\circ} \mathrm{C}$ or $39.5^{\circ} \mathrm{C}$ and the p5 $3^{\text {val } 135}$ mutant at $37^{\circ} \mathrm{C}$ or $39.5^{\circ} \mathrm{C}$ were each bound to the cellular heat shock protein hsc70 in extracts from these cells. p53 val135 failed to bind to hsc 70 when grown at $32.5^{\circ} \mathrm{C}$. These data

Table 1. Detection of wild-type and mutant forms of p53 in p53 plus ras-transformed cells at $39.5^{\circ}, 37^{\circ}$, and $32.5^{\circ} \mathrm{C}$

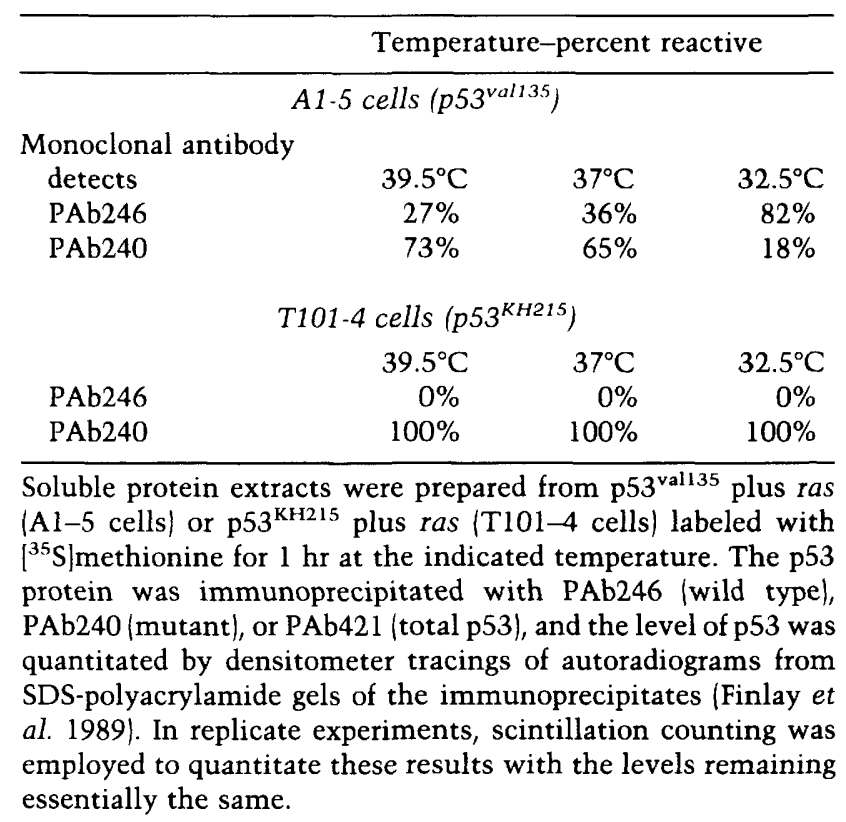


suggest that the $\mathrm{p} 53^{\mathrm{val135}}$ allele is temperature sensitive, in agreement with Michalovitz et al. (1990).

When A1-5 cells (p53 val135) and T101-4 cells $\left(\mathrm{p} 53^{\mathrm{KH} 215}\right)$, grown at $37^{\circ} \mathrm{C}$, were stained with fluorescent antibodies that detect the wild-type p53 (PAb246) or both mutant and wild-type p53 (PAb421), the PAb246 antibody detected nuclear p53 in a punctate pattern in A1 -5 cells (at $37^{\circ} \mathrm{C}, 35 \%$ of the p53 is wild type). PAb246 failed to detect any wild-type p53 in p53 $3^{\mathrm{KH} 215}$ transformed cells (T101-4; Fig. 1). The PAb421 antibody detects p53 predominantly in the cytoplasm of T101-4 cells and both nuclear and cytoplasmic p53 in Al-5 cells.

Because the great majority of p53 in these cells derives from the murine p53 transgene (Finlay et al. 1988), it is unlikely that these fluorescent probes detect the rat endogenous $\mathrm{p} 53$ protein. To determine whether the rat $\mathrm{p} 53$ protein was a mutant or wild-type p53, we amplified a cDNA copy of the rat p53 by PCR and sequenced it directly (see Materials and methods). Both the Al-5 and the T101-4 cells had wild-type rat p53 mRNAs. Thus, these transformed cells have a mixture of mutant p53 and wild-type p53, whereas the mutant form is usually in the highest concentration because it has a longer halflife (Reich and Levine 1984).

\section{Intracellular localization of p53 $3^{\text {vall } 35}$ changes with incubation temperature}

The murine $\mathrm{p} 53^{\mathrm{val} 135}$ mutant has recently been shown to be temperature-sensitive for transforming activity. At $32.5^{\circ} \mathrm{C}$, it is unable to cooperate with ras in transformation assays, yields no foci, and behaves in a wild-type manner (Michalovitz et al. 1990). A1-5 cells contain this temperature-sensitive mutant, whereas T101-4 cells express $\mathrm{p} 53^{\mathrm{KH} 215}$, which is not temperature sensitive for the mutant phenotype. These cell lines were compared to determine the effect of incubation temperature on the subcellular localization of total (PAb421) murine p53 proteins (Fig. 2). p53 ${ }^{\mathrm{KH} 215}$ remained cytoplasmic regardless of the incubation temperature. In A1-5 cells incu-

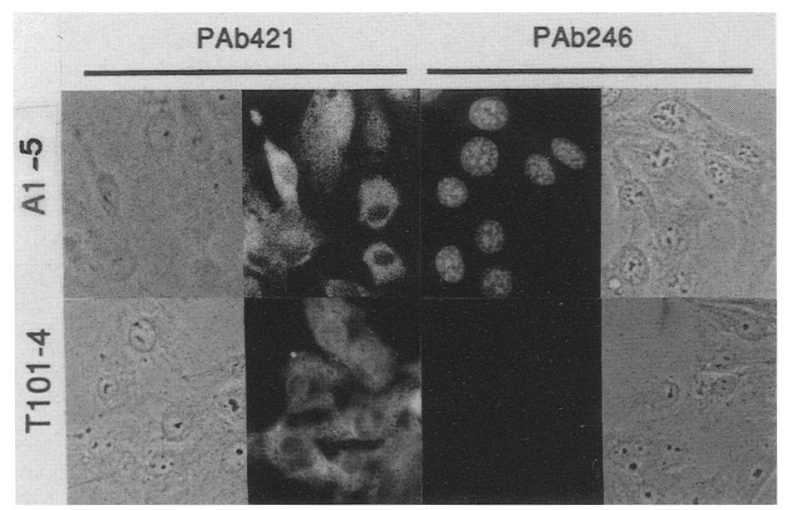

Figure 1. A1-5 and T101-4 cells stained by indirect immunofluroescence with PAb421 and PAb246. Cells were grown on coverslips at $37^{\circ} \mathrm{C}$ and stained as described. Phase-contrast photomicrographs are included for reference.

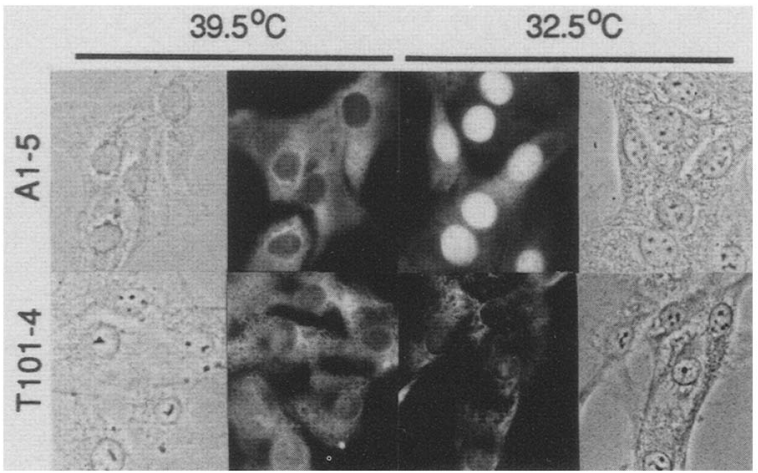

Figure 2. p53 val135 intracellular localization in Al-5 and T1014 cells at $39.5^{\circ} \mathrm{C}$ and $32.5^{\circ} \mathrm{C}$. Cells were grown on coverslips for $48 \mathrm{hr}$ at $39.5^{\circ} \mathrm{C}$ and $32.5^{\circ} \mathrm{C}$ and were fixed and stained by indirect immunofluorescence with PAb421. Phase-contrast photomicrographs are included for reference.

bated at $39.5^{\circ} \mathrm{C}, \mathrm{p} 53^{\text {val135 }}$ was mainly cytoplasmic and the staining pattern was similar to that seen in T101-4 cells. Conversely, at $32.5^{\circ} \mathrm{C}$, p $53^{\text {vall35 }}$ was localized in the nucleus soon after a shift down in temperature at all stages of the cell cycle. Therefore, at low temperature, when the protein is in the wild-type configuration, it is concentrated in the nucleus.

The p53 wild-type protein in a transformed cell alters its intracellular location as a function of the cell cycle

The A1-5 cells at $37^{\circ} \mathrm{C}$ contain a mixture of murine mutant p53 and wild-type murine and rat wild-type p53 in the cell. The nuclear and cytoplasmic localization of these p53 molecules (Figs. 1 and 2) suggested the possibility that different stages of the cell cycle might affect the location of p53 in the cell. To test this, Al-5 cells were synchronized by selective mitotic detachment. These cultures were pulse-labeled with $\left[{ }^{3} \mathrm{H}\right]$ thymidine to determine the time of entry into $\mathrm{S}$ phase or stained by indirect immunofluorescence using PAb246 to examine the intracellular location of the wild-type p53 /conformation) in these cells. The results of this experiment are presented in Fig. 3. $\left[{ }^{3} \mathrm{H}\right]$ Thymidine incorporation (i.e., entry into $S$ phase) begins $3 \mathrm{hr}$ after mitosis (the generation time of these cells was $13 \mathrm{hr}$ ) and reaches a maximum by $4 \mathrm{hr}$. Mitotic cells all have wild-type (but not mutant) p53 attached to the chromosomes in the cell (zero time). At $1-2 \mathrm{hr}$, virtually all of the cells contained p53 (wild-type p53) in the cytoplasm (Fig. 3). As the cells entered $\mathrm{S}$ phase, the percentage of cells with wild-type p53 in the nucleus increased in parallel with the increase in $\left[{ }^{3} \mathrm{H}\right]$ thymidine incorporation. By $4 \mathrm{hr}$, most cells had the punctate staining pattern of nuclear p53, which continued through $S$ phase. Throughout $G_{1}, A 1-5$ cells do not show any nuclear staining for p53 with PAb246 (Fig. 3 , wild-type) or PAb421 (total p53, not shown). The wildtype conformation of p53 is excluded from the cell nucleus during the $G_{1}$ phase of the cell cycle. It enters the nucleus as the cells enter $S$ phase. Interestingly, this is 
Figure 3. Determination of initiation of DNA replication and intracellular distribution of $\mathrm{p}^{\mathrm{val135}}$ in synchronized $\mathrm{A} 1-5$ cells. (A) Al-5 cells were synchronized by mitotic detachment, incubated at $37^{\circ} \mathrm{C}$, and analyzed for TCA-precipitable $\left[{ }^{3} \mathrm{H}\right]$ thymidine incorporation (O). The percent of $\mathrm{p} 53$ positive nuclei was determined after indirect immunofluorescence using PAb246 ( $\mid$ ). (B) Synchronized Al-5 cells grown on coverslips were stained with PAb246 at hourly intervals. A representative field for each sample time point is presented. Phase-contrast photomicrographs are included for reference.

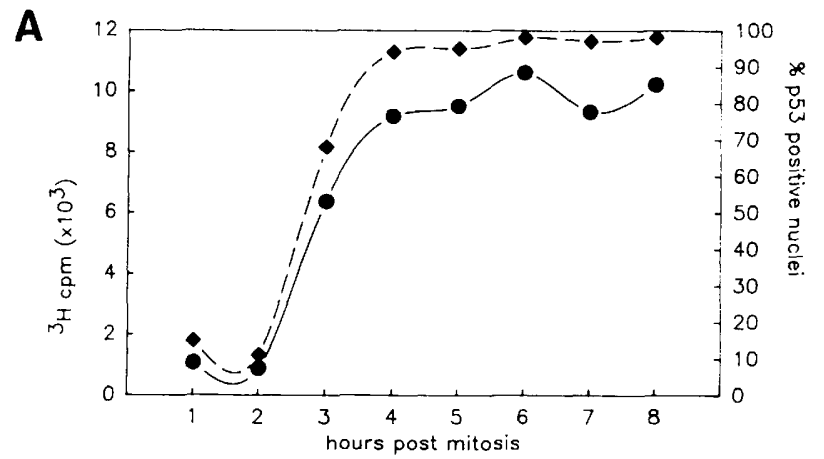

B

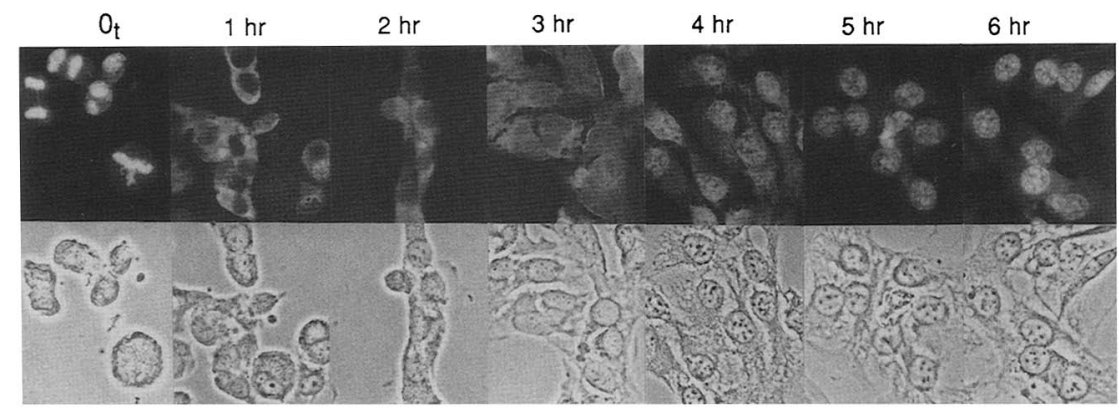

the same pattern of cell localization reported for hsp70 in a cell (Milarski and Morimoto 1986). T101-4 cells contain no wild-type murine p53 and has all of its p53 (PAb421) in the cytoplasm throughout the cell cycle (results not shown).

\section{p53 localization affects cell growth}

p53 is a nuclear protein and has been implicated in growth control of the cell. In Al-5 cells, the subcellular localization of $\mathrm{p} 53^{\mathrm{val} 135}$ can be varied by changing the incubation temperature. On this basis, the effect of a p53 nuclear versus cytoplasmic compartmentalization on cell growth was investigated. Doubling times of six different cell lines were determined at $32.5^{\circ} \mathrm{C}, 37^{\circ} \mathrm{C}$, and $39.5^{\circ} \mathrm{C}$ (Table 2). The following cell lines were studied: $\mathrm{A} 1-5 ; \mathrm{B} 4$, an independently isolated cell line also ex-

Table 2. Doubling times of p53-transformed cells, Rat-1 cells, and primary REFs at three incubation temperatures

\begin{tabular}{|c|c|c|c|c|}
\hline \multirow[b]{2}{*}{ Cell line } & \multirow{2}{*}{$\begin{array}{l}\text { Transforming } \\
\text { p53 mutant }{ }^{\mathrm{a}}\end{array}$} & \multicolumn{3}{|c|}{ Doubling time (hr) } \\
\hline & & $39.5^{\circ} \mathrm{C}$ & $37^{\circ} \mathrm{C}$ & $32.5^{\circ} \mathrm{C}^{\mathrm{b}}$ \\
\hline$A 1-5$ & p5 $53^{\text {val135 }}$ & 13 & 13 & * \\
\hline B4 & p53 & 15 & 18 & * \\
\hline T101-1 & p53 $3^{\text {KH215 }}$ & 18 & 20 & 54 \\
\hline T101-4 & $\mathrm{p} 53^{\mathrm{KH} 215}$ & 14 & 22 & 41 \\
\hline Rat-1 & NA & 13 & 14 & 44 \\
\hline REF & NA & 18 & 19 & 31 \\
\hline
\end{tabular}

(NA) Not applicable.

b $(*)$ Cells remained viable but did not divide. pressing the $\mathrm{p} 53^{\mathrm{val135}}$ mutant; T101-4; T101-1, an independently isolated clone also containing the p53 $3^{\mathrm{KH} 215}$ mutant; Rat-1, an immortalized rat embryo fibroblast cell line; and secondary rat embryo fibroblasts, which are not immortalized. Growth of Al-5 (Fig. 4) and B4 cells (Table 2) that express p $53^{\text {val } 135}$ was arrested at $32.5^{\circ} \mathrm{C}$. All other cell lines slow their growth considerably at $32.5^{\circ} \mathrm{C}$ but continue to grow and divide. Viability of Al-5 cells maintained at $32.5^{\circ} \mathrm{C}$, as assayed by trypan blue exclusion, is $100 \%$ even when incubated for periods of up to 1 week at the low temperature. These cells continue to synthesize proteins and are capable of incorporating $\left[{ }^{35} \mathrm{~S}\right]$ methionine at rates nearly equal to that of cells grown at $37^{\circ} \mathrm{C}$ (results not shown). Finally, the rate of $\left[{ }^{3} \mathrm{H}\right]$ thymidine incorporation for Al-5 cells grown at

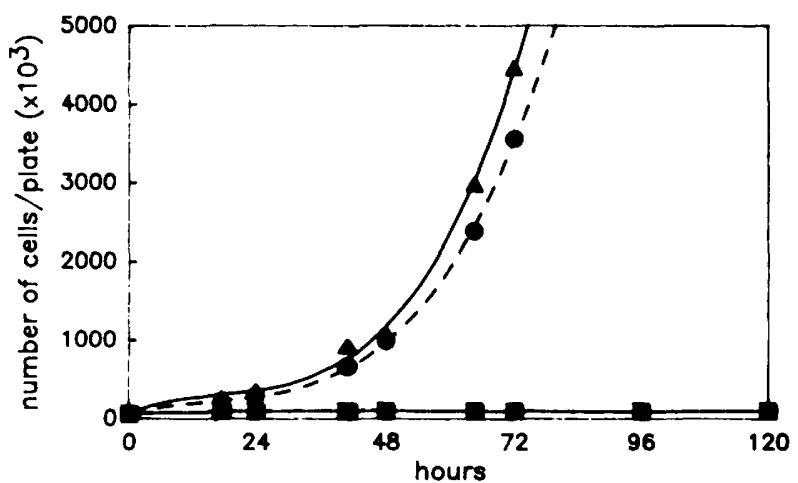

Figure 4. Growth curves of Al-5 cells at $39.5^{\circ} \mathrm{C}(\mathbf{\Delta}), 37^{\circ} \mathrm{C}$ and $32.5^{\circ} \mathrm{C}(\square)$. 
$32.5^{\circ} \mathrm{C}$ drops sevenfold when shifted from $37^{\circ} \mathrm{C}$ to $32.5^{\circ} \mathrm{C}$, whereas $\mathrm{T} 101-4$ cells continue at only slightly reduced levels (data not shown). Therefore, growth inhibition of A1-5 cells by incubation at $32.5^{\circ} \mathrm{C}$ does not appear to result from nonspecific toxicity of $\mathrm{p} 53^{\text {val135. }}$. Since $\left[{ }^{3} \mathrm{H}\right]$ thymidine incorporation was reduced at the low temperature, it was expected that DNA synthesis might be impaired.

\section{Inhibitory effects of p53 on cell growth are restricted} to $G_{1}$

In A1-5 cells grown at $37^{\circ} \mathrm{C}$, p53 val135 had a cytoplasmic location during $\mathrm{G}_{1}$ (Fig. 2). Incubation at $32.5^{\circ} \mathrm{C}$ resulted in nuclear localization of $\mathrm{p} 53^{\mathrm{val135}}$ accompanied by cell growth inhibition (Figs. 2 and 4). As a next step, growthinhibited A1-5 cells at $32.5^{\circ} \mathrm{C}$ were tested to determine whether they were blocked at a specific point in the cell cycle. Al-5 cells maintained for $48 \mathrm{hr}$ at $39.5^{\circ} \mathrm{C}, 37^{\circ} \mathrm{C}$, and $32.5^{\circ} \mathrm{C}$ were lysed and the nuclei were treated with ethidium bromide and analyzed by flow cytometry (Fig. 5 , Table 3 ). At $32.5^{\circ} \mathrm{C}, 91 \%$ of the cells were in $\mathrm{G}_{1}$; less than one-tenth of all the cells are present in $S$ and $G_{2}$. In contrast, the profiles for cells growing at $37^{\circ} \mathrm{C}$ and at $39.5^{\circ} \mathrm{C}$ are indicative of normal exponential growth. Therefore, it appears likely that the progression of A1-5

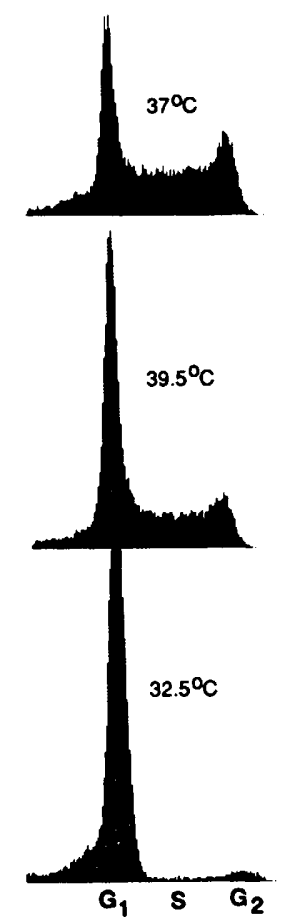

Figure 5. Histograms of Al-5 cells incubated for $48 \mathrm{hr}$ at $39.5^{\circ} \mathrm{C}, 37^{\circ} \mathrm{C}$, or $32.5^{\circ} \mathrm{C}$. Nuclei were prepared and analyzed by flow cytometry. Relative DNA content is represented on the $x$-axis; cell numbers are on the $y$-axis. Cell cycle fractions $G_{1}, S$, and $G_{2}$ are indicated; the percent of total cells in each fraction is presented in Table 1 .
Table 3. Percent of A1-5 cells in $G_{1}, S$, and $G_{2}$ at three incubation temperatures

\begin{tabular}{cccc}
\hline \multirow{2}{*}{$\begin{array}{l}\text { Incubation } \\
\text { temperature }\left({ }^{\circ} \mathrm{C}\right)\end{array}$} & \multicolumn{3}{c}{ Cell cycle fraction $(\%)$} \\
\cline { 2 - 4 } & $\mathrm{G}_{1}$ & $\mathrm{~S}$ & $\mathrm{G}_{2}$ \\
\hline 39.5 & 51 & 31 & 18 \\
37 & 35 & 42 & 23 \\
32.5 & 91 & 4 & 5 \\
\hline
\end{tabular}

cells incubated at $32.5^{\circ} \mathrm{C}$ is impeded at the $G_{1}$ phase of the cell cycle.

The results in Figure 5 provide a static profile of the cells maintained at the three temperaturf : It would be informative to explore the changes tha ccur when a rapidly growing population of Al-5 cell aintained at high temperature are shifted to low te; erature. Logphase cultures of A1-5 cells growing $3 ; 39.5^{\circ} \mathrm{C}$ were shifted to $32.5^{\circ} \mathrm{C}$ and analyzed by flow cytometry (Fig. 6). This demonstrated that cells in $G_{1}$ did not advance through the cell cycle. However, the shift from $39.5^{\circ} \mathrm{C}$ to $32.5^{\circ} \mathrm{C}$ did not retard the progression of cells already in $\mathrm{S}$ phase through the remainder of the cycle (Fig. 6). The block was coincident with a rapid shift in $\mathrm{p} 53^{\text {val135 }}$ localization from cytoplasm to nucleus, as seen by immunofluorescent staining. Interruption of cell cycle progression by shifting to low temperature appears to affect only those cells that have not yet entered $S$ phase. These data are most consistent with the possibility that $\mathrm{p} 53^{\text {val135 }}$ functions at $32.5^{\circ} \mathrm{C}$ during $G_{1}$ as a growth inhibitor and

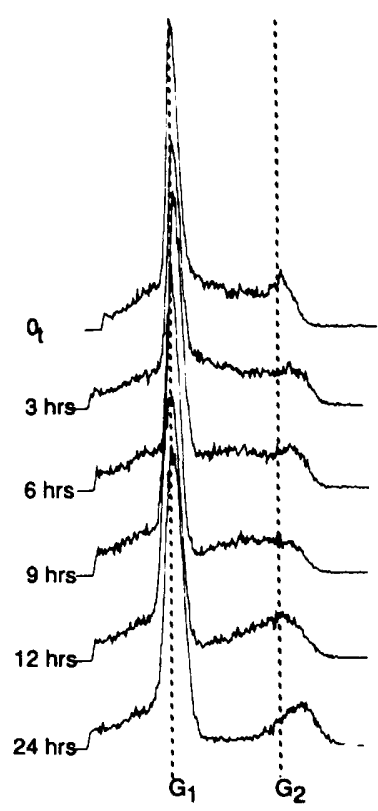

Figure 6. Histograms of A1-5 cells shifted down from $39.5^{\circ} \mathrm{C}$ to $32.5^{\circ} \mathrm{C}$. Samples were analyzed by flow cytometry. Histograms are aligned relative to their $G_{1}$ peaks. The time point of each sample is indicated. 
that cells in S phase are not affected by this inhibitory activity.

To confirm this conclusion, the progression of cells through the cell cycle was compared when they were synchronized and allowed to progress to $G_{1}$ or $S$ phase prior to a shift to $32.5^{\circ} \mathrm{C}$. Al-5 cells were synchronized by mitotic detachment, aliquoted into $60-\mathrm{mm}$ plates, and divided into two groups. $G_{1}$-phase cells were obtained by incubating mitotic cells at $37^{\circ} \mathrm{C}$ for $1 \mathrm{hr}$ and shifting to $32.5^{\circ} \mathrm{C}$. The S-phase group was maintained at $37^{\circ} \mathrm{C}$ for $4 \mathrm{hr}$ before shifting to $32.5^{\circ} \mathrm{C}$. All samples were analyzed by flow cytometry (Fig. 7). From the results obtained in the experiment shown in Figure 3, it was expected that $1 \mathrm{hr}$ at $37^{\circ} \mathrm{C}$ was sufficient time to allow mitosis to be completed but not long enough for DNA replication to be initiated. Furthermore, when incubation is continued for $4 \mathrm{hr}$, cells incorporate $\left[{ }^{3} \mathrm{H}\right]$ thymidine and are thus committed to entering $\mathrm{S}$. The profiles of cells moving through the cell cycle show clearly that preincubation at $37^{\circ} \mathrm{C}$ for $4 \mathrm{hr} / \mathrm{S}$ phase progression; Fig. 7B $\mid$ is sufficient to allow some cells to escape the $G_{1}$ block imposed by incubation at the low temperature. These data suggest that the temperature-associated block in the cell cycle occurs prior to initiation of DNA replication. Once replication has begun, the cell cycle continues unhindered until $G_{1}$ is encountered once again.

\section{Discussion}

Normal or untransformed cells contain very low levels

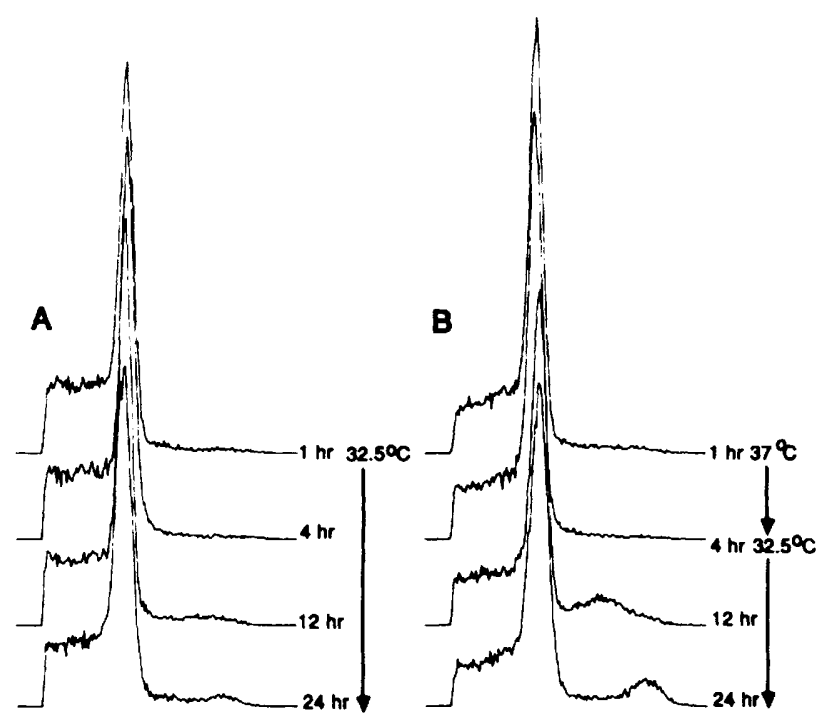

Figure 7. $(A)$ Progression of Al-5 cells synchronized to $\mathrm{G}_{1}$. Al5 cells synchronized by mitotic detachment were preincubated at $37^{\circ} \mathrm{C}$ for $1 \mathrm{hr}$ and shifted to $32.5^{\circ} \mathrm{C}$. $(B)$ Progression of Al-5 cells synchronized to the $S$ phase. Al-5 cells synchronized by mitotic detachment were preincubated at $37^{\circ} \mathrm{C}$ for $4 \mathrm{hr}$ and shifted to $32.5^{\circ} \mathrm{C}$. All samples were analyzed by flow cytometry. Histograms are aligned relative to $G_{1}$ peaks. The postmitotic time is indicated at right. The incubation temperature protocol is also indicated for each group. of p53 (Linzer and Levine 1979), which has made it very difficult to study this protein in these cells. Expressing higher levels of wild-type p53 appears to suppress cell growth (Baker et al. 1990; Diller et al. 1990; Mercer et al. 1990; Michalovitz et al. 1990|, further complicating the study of p53 function in these cells. Mutant p53, on the other hand, cooperates with the ras oncogene to transform cells (Eliyahu et al. 1984; Parada et al. 1984), and high levels of mutant p53 proteins are found in these cells. Several biochemical and immunological criteria have been used to distinguish between the mutant and wild-type p53 proteins (Levine 1990): (1) PAb246 binds to wild-type but not most mutant p53 proteins (Tan et al. 1986; Yewdell et al. 1986); (2) PAb240 binds to many mutant proteins but not to wild-type p53 proteins (Bartek et al. 1990); (3) many mutant p53 proteins form a complex with hsc70 in the cell (Hinds et al. 1987); (4) the half-life is longer and the cellular concentrations of mutant p53 proteins are higher than wild-type p53 (Finlay et al. 1989). Recently, Michalovitz et al. (1990), have shown that the $p 53^{\text {val135 }}$ mutant is temperature sensitive. In this study we confirmed that observation with each of the criteria stated above. At $32.5^{\circ} \mathrm{C}$ the great majority of the p53 val135 protein is wild type, at $39.5^{\circ} \mathrm{C}$ most of it is mutant, and in A $1-5$ cells at $37^{\circ} \mathrm{C}$ a mixture of these two forms has been shown previously to coexist (Hinds et al. 1987; Finlay et al. 1988). This mixture of mutant and wild-type forms of p53 in Al-5 cells may be a good model system to ask the question, how can mutant p53 have a trans-dominant phenotype, eliminating the negative regulatory functions of wild-type p53 (Finlay et al. 1989)? The hypothesis put forth to explain this observation was that murine mutant p53-hsc70 and murine and rat wildtype p53 in these cells was in a complex that inactivated the p53 wild-type function. The results presented in this report provide a mechanism to explain the dominant loss of function mediated by mutant p53. First, the results of a shift of A1-5 cells from $39.5^{\circ} \mathrm{C}$ to $32.5^{\circ} \mathrm{C}$ strongly suggests that wild-type p53 acts in $G_{1}$ to block cells from entering the $S$ phase of the cell cycle. Second, in Al-5 cells at $37^{\circ} \mathrm{C}$ wild-type p53 is sequestered, likely by its association with mutant p53-hsc 70 (Hinds et al. 1987) in the cytoplasm in $G_{1}$ and cannot act in the nucleus at that time. When wild-type p53 returns to the nucleus in $S$ phase, possibly as a result of the movement of hsc70 into the nucleus at that time (Milarski and Morimoto 1986), it is too late in the cell cycle to function and block progression through the cell cycle.

In addition to providing a mechanism for mutant p53 to act in a dominant-negative (loss of function) fashion, the results reported here suggest that wild-type p53 acts during the $G_{1}$ phase of the cell cycle. This result is in good agreement with Diller et al. (1990) and Michalovitz et al. (1990). The only caution in all of these observations is that the wild-type p53 levels required to observe these effects are higher than levels normally seen in cells. This is really an overexpression phenotype. This communication is the first report of the genotype of the p53 alleles from rat cells transformed by mutant murine p53 plus ras. In both $\mathrm{p} 53^{\mathrm{val135}}$ and $\mathrm{p} 53^{\mathrm{KH} 215}$ plus ras-transformed 
cell lines, the endogenous rat p53 is wild type. It remained possible that the endogenous rat cell p53 gene had sustained a mutation to produce a permanent transformed cell line. Many permanent cell lines in culture have been shown to have mutant $\mathrm{p} 53$ genes and proteins (Finlay et al. 1988; Levine 1990). On the contrary, the two different mutant p53 plus ras rat embryo fibroblast cell lines examined here each had wild-type endogenous rat p53 mRNAs, consistent with the trans-dominant inactivation of a negative regulator by mutant murine p 53 proteins. This is based on the assumption that $\mathrm{p} 53^{\text {vall35 }}$ in its wild-type conformation is a good model for studying the behavior of the wild-type rat $\mathrm{p} 53$ protein.

Finally, there are some suggestions in this study that p53 does not act (in a mutant or wild-type form) only as a negative regulator of cell growth. First, the punctate pattern observed in the nuclei of Al-5 cells grown at $37^{\circ} \mathrm{C}$ and stained with PAb246 (wild-type p53; Fig. 3) is not observed in these same cells at $32.5^{\circ} \mathrm{C}$ (Fig. 2). The wild-type p53 protein in cells that are actively replicating their DNA (having allowed cells to enter S phase) behaves differently (has a different nuclear distribution) in $S$ phase than when it is in the nucleus in $G_{1}$ (at $32.5^{\circ} \mathrm{C}$. Similarly, the wild-type p 53 protein (and not the mutant form/ binds tightly to metaphase chromosomes (Fig. 3B). This has also been observed with wild-type p53 in nontransformed cells (rat embryo fibroblast cells; results not presented). Third, the results presented here would predict that wild-type p53 proteins that failed to enter the nucleus (because they have lost their nuclear localization signals $\mid$ would also fail to suppress transformation of cells by p 53 plus ras or E1A plus ras. That is, p53 must mediate its suppressive effects by acting in the nucleus of a cell. This has recently been tested (G. Shaulsky, N. Goldfinger, M. Tosky, A. Levine, and V. Rotter, in press) and is correct. Wild-type $\mathrm{p} 53$ proteins without a nuclear localization signal fail to suppress transformation of cells in culture. On the other hand, one might predict that mutant $\mathrm{p} 53$ proteins that are activated for transformation, but lack a nuclear localization signal, would transform cells in culture by cooperating with ras. In this case, being sequestered in the cytoplasm seems to constitute a mechanism to effect a dominant loss of function for the endogenous wild-type p53. This hypothesis is being tested.

\section{Materials and methods}

\section{Cells and antibodies}

$\mathrm{Al}$ and $\mathrm{B} 4$ cells are primary rat embryo fibroblasts transformed by transfection with activated ras (T24) (Goldfarb et al. 1982) and plasmid LTR p53cG, which directs overexpression of p53 $3^{\text {vali35 }}$ (Finlay et al. 1988). These two cell lines were derived from separate transformation experiments. A1-5 cells were derived from the Al line by limiting dilution and were used throughout these studies, except where indicated. Cell lines T101-1 and T101-4 are rat embryo fibroblasts transformed by transfection with activated ras (T24) and plasmid MSUKH215, which directs the overexpression of $\mathrm{p} 53^{\mathrm{KH} 215}$. These two cell lines are independent clones from the same transformation ex- periment and have been described in detail elsewhere (Finlay et al. 1988). Rat-1 cells were derived from methylcholanthrenetreated Fisher rat embryo fibroblasts (Freeman et al. 1973). Rat embryo fibroblasts are secondary or tertiary cultures. Culture medium for all cells was Dulbecco's modified Eagle medium (DMEM) supplemented with $10 \%$ heat-inactivated fetal calf serum (FCS) at $37^{\circ} \mathrm{C}$, except where stated otherwise.

PAb421 is a pan-specific monoclonal antibody that detects p53 from all species (Harlow et al. 1981). PAb246 recognizes a specific conformational epitope present only on wild-type murine p53 (Yewdell et al. 1986). PAb240 is specific for mutant murine p53 proteins (Gannon et al. 1990).

\section{Indirect immunofluorescent staining}

Coverslips with attached cells were rinsed three times in ice cold PBS [137 mM NaCl, $2.7 \mathrm{mM} \mathrm{KCl}, 4.3 \mathrm{mM} \mathrm{Na}_{2} \mathrm{HPO}_{4} \cdot 7 \mathrm{H}_{2} \mathrm{O}$, $1.4 \mathrm{mM} \mathrm{KH} \mathrm{PO}_{4}(\mathrm{pH}$ 7.3)]. The cells were fixed in methanol/ acetone $\{50: 50\}$ for $2 \mathrm{~min}$ at $-20^{\circ} \mathrm{C}$ and rehydrated with cold PBS. Undiluted monoclonal antibody cell culture supernatants were applied to the coverslips and incubated in a humidified atmosphere for $2 \mathrm{hr}$ at $37^{\circ} \mathrm{C}$. After washing three times with cold PBS, FITC-conjugated sheep $\mathrm{F}\left(\mathrm{ab}^{\prime}\right) 2$ fragment anti-mouse IgG (heavy and light chains) (Cooper Biomedical, Inc., Malvern, PA) diluted 1:50 was added. The coverslips were incubated for $30 \mathrm{~min}$ at $37^{\circ} \mathrm{C}$ and washed three times with cold PBS. Samples were mounted on glass slides with mounting solution / $1 \times$ PBS, 90\% glycerol, $0.1 \%$ p-phenylenediamine). A Zeiss model IIIRS microscope was used for all observations and photographs.

\section{PCR amplification and DNA sequencing}

Total RNA was isolated as described by Maniatis et al. (1982). cDNA was generated essentially as described by Kawaski (1990), using $5 \mu \mathrm{g}$ of total RNA, except that oligo[d(T) $]_{18}$ was used to prime the reverse transcriptase reaction. On completion of the reverse transcriptase reaction, the enzyme was inactivated by heating to $94^{\circ} \mathrm{C}$ for $56 \mathrm{~min}$. The PCR was performed by adding $80 \mu \mathrm{l}$ of $1 \times \mathrm{PCR}$ buffer $[50 \mathrm{mM} \mathrm{KCL}, 2.5 \mathrm{mM} \mathrm{MgCl}, 10$ $\mathrm{mm}$ Tris- $\mathrm{Cl}$ (pH 8.3), $200 \mu \mathrm{M}$ dNTPs, $0.1 \mathrm{mg} / \mathrm{ml} \mathrm{BSA}$ ), 10 pmoles of $5^{\prime}$ primer $15^{\prime}$-CCTGAAGACTGGATAACTGTCATGGAGGAT-3'), 10 pmoles of $3^{\prime}$ primer (5'-AGAGGGGGCCGAGTACTATCTACAAGGTAA-3'), and 5 units of Taq polymerase (Cetus Emeryville, CA) directly to the cDNA reaction mixture. Rat p53 cDNA was amplified by 30 cycles $11 \mathrm{~min}$ at $94^{\circ} \mathrm{C}, 2 \mathrm{~min}$ at $45^{\circ} \mathrm{C}$, and $3 \mathrm{~min}$ at $72^{\circ} \mathrm{C}$ ). Single-stranded DNA from this reaction was amplified by asymmetric PCR as described by McCabe (1990) and sequenced directly by the dideoxy chain-termination method (Sanger et al. 1977).

\section{Growth curves}

Log-phase cells grown to no more than $80 \%$ confluence were fed fresh media $12-24 \mathrm{hr}$ before they were replated at a density of $5 \times 10^{4}$ cells $/ 60-\mathrm{mm}$ plate. The cells were allowed to attach at $37^{\circ} \mathrm{C}$ for $8-12 \mathrm{hr}$ and were left at $37^{\circ} \mathrm{C}$ or shifted to either $32.5^{\circ} \mathrm{C}$ or $39.5^{\circ} \mathrm{C}$. The initial sample was taken $12-24 \mathrm{hr}$ later (approximately one doubling time). Cell numbers were determined using an Electrozone model 112LTSNBCD/ADC (Particle Data, Inc). All time points were performed in duplicate. Doubling times were calculated by fitting data points to an exponential curve using regression analysis.

\section{Mitotic detachment}

Cells for mitotic detachments were fed fresh culture media 15 
hr prior to the experiment. All cells were grown at $37^{\circ} \mathrm{C}$ to $90 \%$ confluency in Corning T150 flasks (Corning, Chicago, IL). Mitotic cells were harvested by replacing culture media with $6 \mathrm{ml}$ of fresh suspension-modified minimum essential medium (SMEM) and $10 \%$ FCS, prewarmed to $37^{\circ} \mathrm{C}$. After continued incubation at $37^{\circ} \mathrm{C}$ for $30 \mathrm{~min}$, the flasks were shaken rapidly for $15 \mathrm{sec}$. The media now containing mitotic cells were pooled and centrifuged at low speed $\left(4^{\circ} \mathrm{C}\right)$. Cell pellets were resuspended in culture medium (Terasima and Tolmach 1963). This procedure regularly yielded populations that consisted of $70-80 \%$ mitotic cells.

\section{Cell cycle progressions}

For determination of $\mathrm{S}$ phase, synchronized cells obtained by mitotic detachment were aliquoted into $35-\mathrm{mm}$ plates and incubated at $37^{\circ} \mathrm{C}$. At hourly intervals, cells were labeled by replacing culture medium with prewarmed $\left(37^{\circ} \mathrm{C}\right)$ medium containing $50 \mu \mathrm{Ci} / \mathrm{ml}\left[{ }^{3} \mathrm{H}\right]$-thymidine $(73.7 \mathrm{Ci} /$ mmole, Dupont/ New England Nuclear, Boston, MA). Incubation was continued for $15 \mathrm{~min}$ at $37^{\circ} \mathrm{C}$. Samples were harvested by rinsing cell monolayer with ice-cold PBS and applying $1 \mathrm{ml}$ of lysis buffer [10\% SDS, $10 \mathrm{~mm}$ EDTA $(\mathrm{pH} 8.0)]$ directly to the plate. TCAprecipitable radioactivity was determined for each sample by scintillation counting in a Beckman LS5000TD.

Synchronized cells for indirect immunofluorescence studies were resuspended in $5 \mathrm{ml}$ of culture medium and applied to poly-L-lysine-coated coverslips for $10 \mathrm{~min}$ on ice. The coverslips were placed in $35-\mathrm{mm}$ plates with medium and incubated at $37^{\circ} \mathrm{C}$. Coverslips were removed at hourly intervals and prepared for immunofluorescence as described.

Cells for analysis of cell cycle progression using flow cytometry were trypsinized from $60-\mathrm{mm}$ plates and lysed in FACS buffer $(3.4 \mathrm{mM} \mathrm{Na}$ citrate, $10 \mathrm{~mm} \mathrm{NaCl}, 0.1 \% \mathrm{NP}-40,75 \mathrm{~mm}$ ethidium bromidel. The cell nuclei were either analyzed immediately, or pelleted, resuspended in freezing buffer $[10 \mathrm{~mm}$ Tris$\mathrm{Cl}(\mathrm{pH} 7.5), 10 \%$ sucrose], and stored at $-70^{\circ} \mathrm{C}$ for analysis at a later date (Sherley and Kelly 1988).

\section{Temperature shift assays and flow cytometry analysis}

Cells were plated at a density of $5 \times 10^{5}$ cells $/ 10-\mathrm{cm}$ plate and incubated at $37^{\circ} \mathrm{C}$ overnight to allow attachment. For shiftdown experiments, plates were incubated at $39.5^{\circ} \mathrm{C}$ for $24 \mathrm{hr}$ and shifted to $32.5^{\circ} \mathrm{C}$. Samples were taken at appropriate intervals and prepared for analysis by flow cytometry as described (Sherley and Kelley 1988). Cells for indirect immunofluorescent staining were grown on coverslips and subjected to the same temperature-shift protocols.

\section{Acknowledgments}

We are grateful to James Sherley for stimulating and productive discussions and to Jerome Zawadzki for help with flow cytometry analysis. Thanks go to Kate James for her patience in preparing this manuscript. This work was supported by National Institutes of Health grant CA38757.

The publication costs of this article were defrayed in part by payment of page charges. This article must therefore be hereby marked "advertisement" in accordance with 18 USC section 1734 solely to indicate this fact.

\section{References}

Baker, S.J., S. Markowitz, E.R. Fearon, J.K.U. Wilson, and B. Vogelstein. 1990. Suppression of human colorectal carcinoma cell growth by wild-type p53. Science (in press).
Bartek, J., R. Iggo, J. Gannon, and D. Lane. 1990. Genetic and immunological analysis of mutant p53 in human breast cancer cell lines. Oncogene 5: 893-899.

Crawford, L.V., D.C. Pim, E.G. Gurney, P. Goodfellow and J. Taylor-Papadimitriou. 1981. Detection of a common feature in several human tumor cell lines-A 53,000-Dalton protein. Proc. Natl. Acad. Sci. 78: 41-45.

Diller, L., J. Kassel, C.E. Nelson, M.A. Gryka, G. Litwak, M. Gebhardt, Bressac, B., Ozturk, M., Baker, S.J., Vogelstein, B., and S.H. Friend. 1990. p53 suppresses the growth of osteosarcoma cells and blocks cell cycle progression. Mol. Cell. Biol. (in press).

Dippold, W.G., G. Jay, A.B. DeLeo, G. Khoury, and L.J. Old. 1981. p53 transformation-related protein: Detection by monoclonal antibody in mouse and human cells. Proc. Natl. Acad. Sci. 78: 1695-1699.

Eliyahu, D., A. Raz, P. Gruss, Givol, D., and M. Oren. 1984. Participation of p53 cellular tumor antigen in transformation of normal embryonic cells. Nature 312: 646-649.

Eliyahu, D., D. Michalovitz, and M. Oren. 1985. Overproduction of p53 antigen makes established cells highly tumorigenic. Nature 316: 158-160.

Eliyahu, D., N. Goldfinger, O. Pinhasi-Kimhi, G. Shaulsky, Y. Skurnik, N. Arai, V. Rotter, and M. Oren. 1988. Meth A fibrosarcoma cells express two transforming mutant p53 species. Oncogene 3: 313-321.

Eliyahu, D., D. Michalovitz, S. Eliyahu, O. Pinhasi-Kimhi, and M. Oren. 1989. Wild-type p53 can inhibit oncogene-mediated focus formation. Proc. Natl. Acad. Sci. 86: 8763-8767.

Finlay, C.A., P.W. Hinds, T.-H. Tan, D. Eliyahu, M. Oren, and A.l. Levine. 1988. Activating mutations for transformation by 553 produce a gene product that forms an hsc 70 -p 53 complex with an altered half-life. Mol. Cell. Biol. 8: 531-539.

Finlay, C.A., P.W. Hinds, A.J. Levine. 1989. The p53 proto-oncogene can act as a suppressor of transformation. Cell 57: 1083-1093.

Freeman, A.E., R.V. Gilden, M.L. Vernon, R.G. Wolford, P.E. Hugunin, and R.J. Huebner. 1973. 5-bromo-2'-deoxyuridine potentiation of transformation of rat-embryo cells induced in vitro by 3-methylcholanthrene: Induction of rat leukemia virus gs antigen in transformed cells. Proc. Natl. Acad. Sci. 70: 2415-2419.

Gannon, J.V., R. Greaves, R. Iggo, and D.P. Lane. 1990. Activating mutations in $\mathrm{p} 53$ produce a common conformational effect: A monoclonal antibody specific for the mutant form. EMBO I. 9: 1595-1602.

Goldfarb, M., K. Shimizu, M. Perucho, and M. Wigler. 1982. Isolation and preliminary characterization of a human transforming gene from T24 bladder carcinoma cells. Nature 296: 404-409.

Harlow, E., L.V. Crawford, D.C. Pim, and N.M. Williamson. 1981. Monoclonal antibodies specific for simian virus 40 tumor antigen. J. Virol. 39: 861-869.

Hinds, P.W., C.A. Finlay, A.B. Frey, and A.J. Levine. 1987. Immunological evidence for the association of $\mathrm{p} 53$ with a heat shock protein, hsc70, in p53-plus-ras-transformed cell lines. Mol. Cell. Biol. 7: 2863-2869.

Hinds, P., C. Finlay, and A.J. Levine. 1989. Mutation is required to activate the p53 gene for cooperation with the ras oncogene and transformation. J. Virol. 63: 739-746.

Iggo, R., K. Gatter, J. Bartek, D. Lane, and A.L. Harris. 1990. Increased expression of mutant forms of p53 oncogene in primary lung cancer. Lancet 335: 675-679.

Kawaski, E.S. 1990. Amplification of RNA. In PCR protocols: $A$ guide to methods and applications. (eds. M.A. Innis, D.H. Gelfand, J.J. Sninsky, and T.J. Whitel, pp. 21-27. Academic 
Press/Harcourt Brace Jovanovich Publishers, New York.

Lane, D.P. and L.V. Crawford. 1979. T antigen is bound to a host protein in SV40-transformed cells. Nature 278: 261-263.

Levine, A.J. 1990. The p53 protein and its interactions with the oncogene products of the small DNA tumor viruses. Virology 177: 419-426.

Linzer, D.I.H. and A.J. Levine. 1979. Characterization of a $54 \mathrm{~K}$ dalton cellular SV40 tumor antigen present in SV40-transformed cells and uninfected embryonal carcinoma cells. Cell 17: 43-52.

Maniatis, T., E.F. Frisch, and J. Sambrook. 1982. Molecular cloning: A laboratory manual, pp. 196. Cold Spring Harbor Laboratory, Cold Spring Harbor, New York.

McCabe, P.C. 1990. Production of single stranded DNA by asymetric PCR. In PCR protocols: $A$ guide to methods and applications (ed. M.A. Innis, D.H. Gelfand, J.J. Sninsky, and T.J. White), pp.76-83. Academic Press./Harcourt Brace Jovanovich Publishers, New York.

Mercer, W.F., M.T. Shields, M. Amin, G.J. Suave, E. Appella, S.J. Ullrich, and J.W. Romano. 1990. Antiproliferative effects of wild-type human p53. J. Cell. Biochem. 14C: 285.

Michalovitz, D., O. Halevy, and M. Oren. 1990. Conditional inhibition of transformation and of cell proliferation by a temperature-sensitive mutant of p53. Cell 62: 671-680.

Milarski, K.L., and R.I. Morimoto. 1986. Expression of human hsp70 during the synthetic phase of the' cell cycle. Proc. Natl. Acad. Sci. 83: 9517-9521.

Parada, L.F., H. Land, R.A. Weinberg, D. Wolf, and V. Rotter. 1984. Cooperation between gene encoding p53 tumour antigen and ras in cellular transformation. Nature 312: 649-651.

Reich, N.C., and A.J. Levine. 1984. Growth regulation of a cellular tumor antigen, p53, in nontransformed cells. Nature 308: 199-201.

Sanger, F., S. Nicklen, and A.R. Coulson. 1977. DNA sequencing with chain-terminating inhibitors. Proc. Natl. Acad. Sci. 14: 5463-5467.

Sarnow, P., Y.S. Ho, J. Williams, and A.J. Levine. 1982. Adenovirus E1B-58Kd tumor antigen and SV40 large tumor antigen are physically associated with the same $54 \mathrm{Kd}$ cellular protein in transformed cells. Cell 28: 387-394.

Sherley, J.L. and T.J. Kelly. 1988. Regulation of human thymidine kinase during the cell cycle. I. Biol. Chem. 263: 83508358.

Tan, T.-H., J. Wallis, and A.J. Levine. 1986. Identification of the p53 protein domain involved in formation of the simian virus 40 large $T$ antigen-p53 protein complex. I. Virol. 59: 574583.

Terasima, T. and L.J. Tolmach. 1963. Growth and nucleic acid synthesis in synchronously dividing populations of $\mathrm{HeLa}$ cells. Exp. Cell Res. 30: 344-362.

Thomas, R., L. Kaplan, N. Reich, D.P. Lane, and A.J. Levine. 1983. Characterization of human p53 antigen employing primate specific monoclonal antibodies. Virology 131: 502517.

Werness, B.A., A.J. Levine, and P.M. Howley. 1990. The E6 proteins encoded by human papillomavirus types 16 and 18 can complex p53 in vitro. Science 248: 76-79.

Yewdell, J., J.V. Gannon, and D.P. Lane. 1986. Monoclonal antibody analysis of p53 expression in normal and transformed cells. I. Virol. 59: 444-452. 


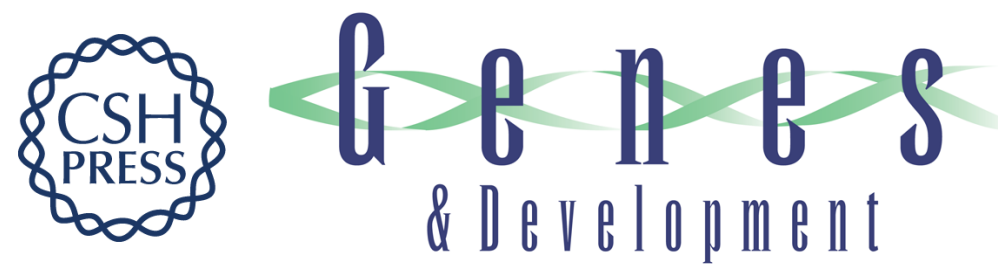

\section{Cellular localization and cell cycle regulation by a temperature-sensitive $\mathbf{p 5 3}$ protein.}

J Martinez, I Georgoff, J Martinez, et al.

Genes Dev. 1991, 5:

Access the most recent version at doi:10.1101/gad.5.2.151

References This article cites 32 articles, 13 of which can be accessed free at:

http://genesdev.cshlp.org/content/5/2/151.full.html\#ref-list-1

License

Email Alerting Receive free email alerts when new articles cite this article - sign up in the box at the top Service right corner of the article or click here.

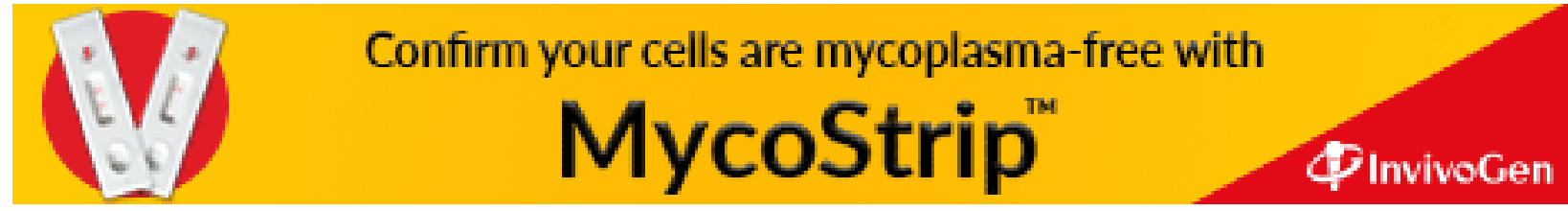

